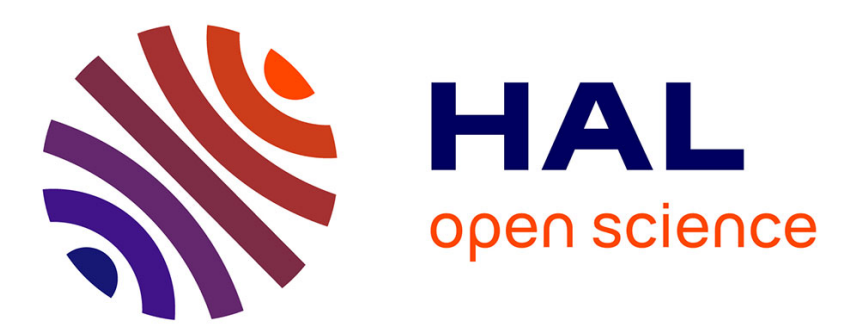

\title{
Imatinib, cytokines and interstitial lung disease in a patient with primary myelofibrosis
}

Bruno Robibaro, Anna Kropfmueller, Mathias Prokop, Paul Haber, Heinz

Gisslinger

\section{- To cite this version:}

Bruno Robibaro, Anna Kropfmueller, Mathias Prokop, Paul Haber, Heinz Gisslinger. Imatinib, cytokines and interstitial lung disease in a patient with primary myelofibrosis. Annals of Hematology, 2009, 89 (8), pp.829-831. 10.1007/s00277-009-0884-6 . hal-00535115

\section{HAL Id: hal-00535115 https://hal.science/hal-00535115}

Submitted on 11 Nov 2010

HAL is a multi-disciplinary open access archive for the deposit and dissemination of scientific research documents, whether they are published or not. The documents may come from teaching and research institutions in France or abroad, or from public or private research centers.
L'archive ouverte pluridisciplinaire HAL, est destinée au dépôt et à la diffusion de documents scientifiques de niveau recherche, publiés ou non, émanant des établissements d'enseignement et de recherche français ou étrangers, des laboratoires publics ou privés. 


\title{
Imatinib, cytokines and interstitial lung disease in a patient with primary myelofibrosis
}

\author{
Bruno Robibaro • Anna Kropfmueller • \\ Mathias Prokop • Paul Haber • Heinz Gisslinger
}

Received: 28 July 2009 /Accepted: 3 December 2009 /Published online: 19 December 2009

(C) Springer-Verlag 2009

\section{Dear Editor,}

Several cases of drug-induced pneumonitis in patients treated with imatinib have been reported to date [1]. Here, we report acute drug-induced pneumonitis necessitating therapy discontinuation in a 54-year-old man with primary myelofibrosis (PMF) treated with imatinib. We extended our observation by serial assessment of serum cytokine levels in an attempt to possibly gain further insight in the pathomechanism causing the adverse pulmonary event.

The patient initially underwent a work up because of unexplained thrombo- $(639,000 / \mu \mathrm{L})$ and leucocytosis (WBC $12,200 / \mu \mathrm{L}$ ). He had splenomegalia, but was otherwise asymptomatic. The bone marrow aspirate revealed a diagnosis of primary myelofibrosis, grade 3 . A specific treatment was initially considered not necessary; however, as the disease became progressive, a therapy with imatinib according to a study protocol investigating the effectiveness of imatinib in PMF was initiated. Imatinib was given in a dosage of $200 \mathrm{mg}$ twice daily, which he had tolerated well over a period of 9 weeks. When imatinib was increased to $600 \mathrm{mg}$ daily, the patient presented with rapidly worsening

\footnotetext{
B. Robibaro $(\square) \cdot$ A. Kropfmueller $\cdot$ P. Haber

Division of Pulmonary Medicine, Medical University Vienna, Waehringer Guertel 18-20,

1090 Vienna, Austria

e-mail: bruno.robibaro@meduniwien.ac.at

\section{Prokop}

Department of Radiology, University Medical Center Utrecht, Heidelberglaan 100,

3584 CX, Utrecht, The Netherlands

\section{H. Gisslinger}

Division of Hematology and Blood Coagulation,

Medical University Vienna,

Waehringer Guertel 18-20,

1090 Vienna, Austria
}

dyspnoea. Arterial blood gas analysis (ABG) showed hypoxemia and signs of impaired alveolar gas diffusion aggravated under exercise (Table 1). The pulmonary function test (PFT) showed a restrictive ventilatory pattern characteristic of interstitial lung disease (Table 2). Chest high-resolution computed tomography (HRCT) showed poorly defined, bilateral patchy infiltrates (Fig. 1a) consistent with drug-induced pulmonary lesions. Imatinib therapy was stopped and therapy with $1 \mathrm{mg} / \mathrm{kg}$ oral prednisolone once daily was started in a tapering fashion and eventually withdrawn after 10 weeks. At the first follow-up visit 9 weeks after the acute episode, the patient's condition had consistently improved. Concomitant with his clinical improvement, ABG and PFT improved (Tables 1 and 2). Radiological follow-up by HRCT also revealed a visible improvement although still showing mild patchy infiltrates and leaving traction bronchiectasis as sign of scarification of lung tissue following drug-induced interstitial pneumonia (Fig. 1b).

Platelet-derived growth factor (PDGF), vascular endothelial growth factor (VEGF), basic fibroblast growth factor (bFGF), and interferon-gamma (IFN- $\gamma$ ) serum concentrations were retrospectively analysed with a specific enzymelinked immunosorbent assay (ELISA, Quantikine, R\&D Systems, Minneapolis, MN, USA) according to manufacturer's instructions. Serum cytokine profiles showed further upregulation of already over the range of reference values in healthy individuals elevated profibrotic and angiogenic cytokines (PDGF, VFGF, and bFGF), whereas a major antifibrotic cytokine, IFN- $\gamma$, was not detectable (Table 3). According to the manufacturer R\&D Systems, the ELISA range of values in healthy subjects for PDGF is 10.499$29.463 \mathrm{pg} / \mathrm{mL}$, VEGF 62-707 pg/mL, bFGF non-detectable to $14.6 \mathrm{pg} / \mathrm{mL}$, and IFN-gamma less than the lowest IFNgamma standard, $15.6 \mathrm{pg} / \mathrm{mL}$. Instead, in our patient, 
Table 1 Arterial blood gas analysis

\begin{tabular}{lll}
\hline Parameter & Acute episode & 9-week follow-up \\
\hline $\mathrm{PaO} 2(\mathrm{mmHg})$ & $65 /(42)$ & $74 /(73)$ \\
$\mathrm{PaCO} 2(\mathrm{mmHg})$ & $37 /(34)$ & $43 /(44)$ \\
$\mathrm{AaDO} 2(\mathrm{mmHg})$ & $41 /(67)$ & $26 /(26)$ \\
$\mathrm{DLCO}(\mathrm{mmol} / \mathrm{minkPa})$ & $3.28(35 \%$ & $6.32(67 \%$ \\
& predicted) & predicted) \\
$\mathrm{DLCO} / \mathrm{VA}(\mathrm{mmol} / \mathrm{minkPa})$ & $1.04(57 \%$ & $1.21(66 \%$ \\
& predicted) & predicted) \\
\hline
\end{tabular}

Arterial blood gas parameters at rest and under exercise (under parenthesis) during acute drug-induced pneumonitis and after discontinuation of imatinib at 9-week follow-up

$\mathrm{PaO} 2$ arterial oxygen pressure, $\mathrm{PaCO} 2$ arterial carbon dioxide pressure, $A a D O 2$ alveolo-arterial oxygen difference, $D L C O$ diffusing capacity for carbon monoxide, $D L C O / V A$ ratio of diffusing capacity for carbon monoxide and alveolar volume

Table 2 Pulmonary function test

\begin{tabular}{lll}
\hline Parameter (\% predicted) & Acute episode & 9-week follow-up \\
\hline VC (L) & $2.17(48 \%)$ & $3.25(73 \%)$ \\
FEV1 (L) & $1.93(53 \%)$ & $2.87(79 \%)$ \\
FEV1\%VC (\%) & $89(107 \%)$ & $88(106 \%)$ \\
TLC (L) & $4.20(66 \%)$ & $5.95(94 \%)$ \\
\hline
\end{tabular}

Pulmonary function test parameters during acute drug-induced pneumonitis and after discontinuation of imatinib at 9-week follow-up $V C$ vital capacity, FEV1 forced expiratory volume in $1 \mathrm{~s}, \mathrm{~F} E V 1 \% V C$ ratio of forced expiratory volume in $1 \mathrm{~s}$ and vital capacity, TLC total lung capacity

cytokine levels were elevated, with VEGF and bFGF being far beyond the reported normal range of healthy subjects. Altogether, the maximal cytokine increase of PDGF, VFGF, and bFGF from the patient baseline value measured before starting imatinib therapy was $41 \%, 55 \%$, and $51 \%$, respectively. Concerning IFN-gamma, as stated above, it is normally not detectable in the serum of healthy individuals but raises most notably during infections. In
Table 3 Serum cytokine concentrations

\begin{tabular}{llll}
\hline Week & PDGF & VEGF & bFGF \\
\hline 0 (base line) & $29,505.55$ & $2,043.89$ & 144.82 \\
9 & $33,545.55$ & $1,908.02$ & 174.66 \\
15 & $41,655.60$ & $2,321.60$ & 218.99 \\
17 & $41,295.45$ & $3,176.96$ & 139.97 \\
19 & $40,204.75$ & $2,038.54$ & 126.52 \\
30 & $34,164.95$ & $2,479.26$ & 86.80 \\
\hline
\end{tabular}

Serum cytokine concentrations (in $\mathrm{pg} / \mathrm{mL}$ ) before, during (week 5week 17) and after therapy with imatinib. Prednisolone was given from week 17 until week 27 in tapering fashion

our patient, IFN-gamma was not detectable at any time during the observation period.

In comparison, in other chronic myeloproliferative disorders, maximal VEGF serum levels were $178 \mathrm{pg} / \mathrm{mL}$, respectively, bFGF $43 \mathrm{pg} / \mathrm{mL}$ in essential thrombocytopenia [2]. In the collagen disease polymyositis/dermatomyositis VEGF serum levels were as high as $352 \mathrm{pg} / \mathrm{mL}$ [3]. In a study examining serum levels of VEGF and bFGF in metastatic cancer patients, the reported preoperative values were up to 479 and $11.4 \mathrm{pg} / \mathrm{mL}$, respectively [4].

Ex vivo cell culture experiments using squamous tumour cells of head and neck carcinoma treated with imatinib resulted in reduced cytokine secretion of PDGF and VEGF [5]. Other in vitro experiments showed antigen-specific inhibition of IFN-gamma production by $\mathrm{T}$ cells [6] and demonstrated increased IFN-gamma production in imatinibtreated T cells of CML patients [7]. A more recent study revealed that imatinib therapy had no effect on the plasma level of VEGF, PDGF, bFGF, but in vitro inhibitory effect on IFN-gamma production [8].

In the present report, we describe the case of a patient with PMF in whom treatment with imatinib led to severe, although reversible, interstitial lung disease. Drug-induced pneumonitis usually represents a severe adverse event described for numerous drugs (more information available at www.pneumotox.com). The pathomechanisms are
Fig. 1 a Chest HRCT showing diffuse bilateral patchy areas of ground glass attenuation and $\mathbf{b}$ a comparable section at 10 -week follow-up
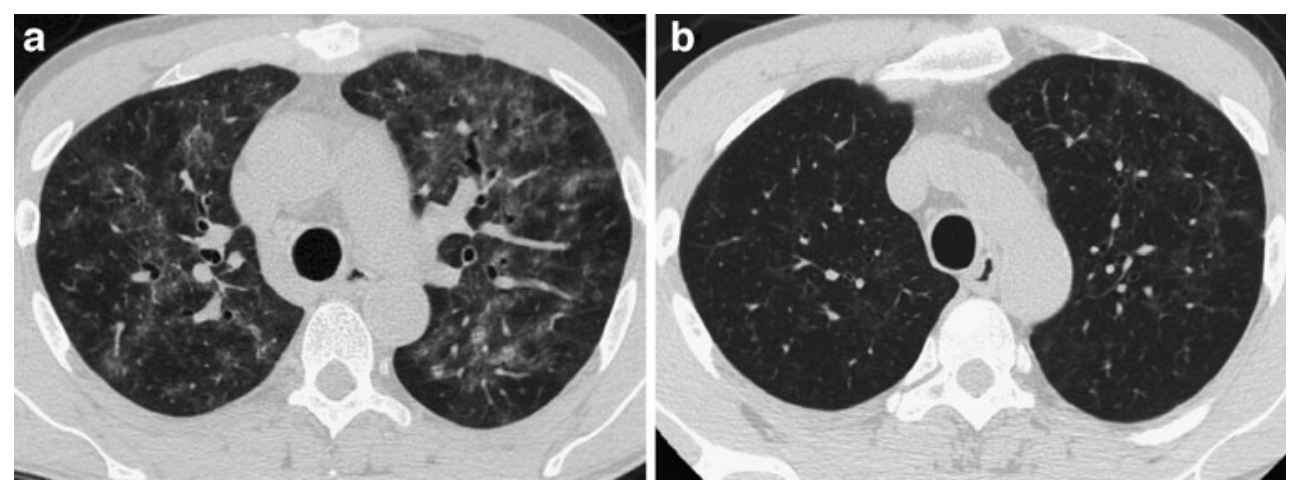
believed to involve accumulation of inflammatory or immune effector cells and a direct toxic mechanism resulting in lung parenchymal cell injury and subsequent fibrotic response. The underlying molecular mechanisms still remain poorly understood. However, experimental models of interstitial lung disease based on bleomycin [9] and radiation injury [10] have shown a pivotal role for cytokines known to have profibrotic properties in the development of interstitial lung disease and beneficial effects in antagonising them. In our particular case, serum cytokine profiles have been monitored showing consistent upregulation of profibrotic and angiogenic cytokines (PDGF, VFGF, and bFGF) akin to the aforementioned reports (Table 3).

Although limited by a single case, this observation suggests that caution should be given under circumstances of upregulated profibrotic and angiogenic cytokines, as those patients may potentially be at risk for developing adverse events based on upregulation of profibrotic mechanisms. Whereas imitanib has been shown to lead to regression of bone marrow fibrosis possibly by an antiPDGF effect and through reduction of tissue growth factor-beta (TGF-beta) release from megakaryocytes [11], profibrotic and angiogenic cytokines tended to be highest during the acute presentation of the adverse event while the patient was taking imatinib, suggesting tissue-specific cytokine responsivity.

In conclusion, our observation suggests to carefully observe pulmonary symptoms in all patients who are receiving imatinib, as early diagnosis and immediate intervention are critical in managing drug-induced interstitial lung disease. In addition, based on this analysis, monitoring the mentioned cytokine profiles could help to timely recognise a "proinflammatory/profibrotic constellation" during imatinib therapy potentially leading to a lifethreatening adverse event. Ultimately, further investigations on a larger scale are needed to elucidate imatinib-related and, in general, the understanding of drug-related interstitial lung disease.

\section{References}

1. Ohnishi K, Sakai F, Kudoh S, Ohno R (2006) Twenty-seven cases of drug-induced interstitial lung disease associated with imatinib mesylate. Leukemia 20:1162-1164

2. Musolino C, Calabro' L, Bellomo G, Martello F, Loteta B, Pezzano C, Rizzo V, Alonci A (2002) Soluble angiogenic factors: implications for chronic myeloproliferative disorders. Am J Hematol 69:159-163

3. Kikuchi K, Kubo M, Kadono T, Yazawa N, IHN H, Tamaki K (1998) Serum concentrations of vascular endothelial growth factor in collagen diseases. Brit J Dermatol 139:1049-1051

4. Dirix LY, Vermeulen PB, Pawinski A, Prové A, Benoy I, De Pooter C, Martin M, Van Oosterom AT (1997) Elevated levels of the angiogenic cytokines basic fibroblast growth factor and vascular endothelial growth factor in sera of cancer patients. Brit J Cancer 76:238-243

5. Bran B, Bran G, Hörmann K, Riedel F (2009) The plateletderived growth factor receptor as a target for vascular endothelial growth factor-mediated anti-angiogenetic therapy in head and neck cancer. Int J Oncol 34(1):255-261

6. Leder C, Ortler S, Seggewiss R, Einsele H, Wiendl H (2007) Modulation of T-effector function by imatinib at the level of cytokine secretion. Exp Hematol 35:1266-1271

7. Aswald JM, Lipton JH, Aswald S, Messner HA (2002) Increased IFN-gamma synthesis by T cells from patients on imatinib therapy for chronic myeloid leukemia. Cytokines Cell Mol Ther 7:143149

8. Cristofanilli M, Morandi P, Krishnamurthy S, Reuben JM, Lee BN, Francis D, Booser DJ, Green MC, Arun BK, Pusztai L, Lopez A, Islam R, Valero V, Hortobagyi GN (2008) Imatinib mesylate $\left(\right.$ Gleevec ${ }^{\mathbb{R}}$ ) in advanced breast cancer expressing C-Kit or PDGFR- $\beta$ : clinical activity and biological correlations. Ann Oncol 19:1713-1719

9. Chaudhary NI, Roth GJ, Hilberg F, Müller-Quernheim J, Prasse A, Zissel G, Schnapp A, Park JE (2007) Inhibition of PDGF, VEGF and FGF signalling attenuates fibrosis. Eur Respir $\mathrm{J}$ 29:976-985

10. Abdollahi A, Li M, Ping G, Plathow C, Domhan S, Kiessling F, Lee LB, McMahon G, Gröne HJ, Lipson KE, Huber PE (2005) Inhibition of platelet-derived growth factor signaling attenuates pulmonary fibrosis. J Exp Med 201:925-935

11. Beham-Schmid C, Apfelbeck U, Sill H, Tsybrovsky O, Hofler G, Haas OA, Linkesch W (2002) Treatement of chronic myelogenous leukemia with the tyrosine kinase inhibitor STI 571 results in marked regression of bone marrow fibrosis. Blood 99:281-283 